\title{
IMPLEMENTASI TATA KELOLALAYANAN PUBLIK UNTUK MEWUJUDKAN GOOD GOVERNANCE PADA PERGURUAN TINGGI
}

\author{
Desi Nurhikmahyanti \\ Universitas Tidar \\ Jl. Kapten Suparman No. 39 Magelang \\ Email: desinurhikmahyanti@untidar.ac.id
}

\begin{abstract}
: the purpose of this study is to describe and analyze the implementation, and constraints of universities in realizing good governance in universities. The method used in this research is case study with qualitative approach. The results of the study found that the implementation of good governance in universities using several principles, namely: transparency, independence, accountability, responsibility, equity and fairness.
\end{abstract}

\section{Keyword: implementation of public services, good governance.}

\begin{abstract}
Abstrak: tujuan penelitian ini adalah mendeskripsikandan menganalisis mengenai implementasi, dan kendala perguruan tinggi dalam mewujudkan good governance pada perguruan tinggi. Metode yang digunakan dalam penelitian ini adalah studi kasus dengan pendekatan kualitatif.Hasil penelitian menemukan bahwa penerapan good governance pada perguruan tinggi dengan menggunakan beberapa prinsip, yaitu: transparansi (transparancy), kemandirian (independence), akuntabilitas (accountability), pertanggungjawaban (responsibility), kesetaraan dan kewajaran (fairness).
\end{abstract}

Kata kunci: implementasi layanan publik, good governance

Penyelenggaraan institusi perguruan tinggi, khususnya perguruan tinggi negeri, perlu mulai ditelaah secara mendalam. Hal ini menjadi penting setelah dalam praktiknya ternyata bermunculan tantangan baru dalam penyelenggaraan sebuah perguruan tinggi. Tantangan baru ini merupakan aspek-aspek yang sebelumnya tidak terlalu diperhitungkan oleh perguruan tinggi negeri di Indonesia, termasuk bagaimana menumbuhkan sumber-sumber pendanaan baru yang produktif, pengelolaan keuangan, kebebasan lebih besar dalam merumuskan kurikulum dan hal-hal lain yang terkait dengan bidang akademis, akuntabilitas publik, dan sebagainya.

Pemikiran-pemikiran baru mulai bermunculan mengenai bagaimana konsep penyelenggaraan institusi perguruan tinggi yang dianggap ideal untuk menghadapi tantangan baru tersebut. Konsep tersebut, apapun bentuknya, nampaknya harus memperhatikan pelibatan dan pemenuhan kebutuhan dari seluruh stakeholders yang terkait dengan institusi perguruan tinggi. Mengingat peranan ideal pendidikan tinggi bagi sebuah bangsa yang sangat vital dalam menghasilkan calon putra-putra terbaiknya dan memperhatikan bahwa lingkungan perguruan tinggi merupakan sebuah komunitas yang relatif kritis terhadap permasalahan-permasalahan disekitarnya (Aristo, 2005:19).

Adapun salah satu konsepyang saat ini sedang menjadi mainstream dalam penyelenggaraan perusahaan publik adalah konsep good corporate governance. Sebagaimana dipahami bahwa good corporate governance merujuk pada bagaimana tata kelola perusahaan yang baik. Aristo (2005:28) mengemukakan wacana konsep serupa untuk perguruan tinggi, yaitu good governance. Konsep good corporate governance sebenarnya merupakan turunan dari konsep tata pemerintahan yang lebih umum, yaitu good governance.

Menurut Brojonegoro (2005:2) menyatakan bahwa Perguruan Tinggi Negeri di Indonesia mengalami kemunduran kualitas, kurang memberikan konstribusi pada perkembangan bangsa dan tertinggal dari perguruan tinggi negara lain. Selain pendanaan yang terbatas, 
penyebab utamanya adalah sistem dan organisasi pengelolaan pendidikan tinggi yang dinilai kurang sehat dan sentralistik. Perlu dikembangkan kebijakan dan paradigma baru pengelolaan pendidikan tinggi yang berbasis otonomi dan kesehatan organisasi untuk meningkatkan daya saing bangsa. Perguruan tinggi harus mampu memandang dan menempatkan dirinya dalam perspektif yang relatif diantara berbagai perguruan tinggi lainnya di dunia. Perguruan tinggi di Indonesia secara umum memiliki daya saing yang masih rendah di level internasional.

Berdasarkan paparan latar belakang di atas maka rumusan masalah penelitian ini adalah sebagai berikut: (1) bagaimana implementasi yang dilakukan oleh senat, rektor dan pembantu rektor, kepala biro, dekan dan pembantu dekan, pejabat struktural, dosen, pimpinan unit, dan karyawan dalam penerapan tata kelola layanan publik untuk mewujudkan good governance pada perguruan tinggi di Universitas Negeri Surabaya (Unesa), dan (2) bagaimanakendala yang dialami oleh senat, rektor dan pembantu rektor, kepala biro, dekan dan pembantu dekan, pejabat struktural, dosen, pimpinan unit, dan karyawan dalam implementasi tata kelola layanan publik untuk mewujudkan good governance pada perguruan tinggi di Universitas Negeri Surabaya (Unesa)?

Untuk mengerti lebih mendalam mengenai apa yang dimaksud dengan corporate governance, maka perlu disimak beberapa rumusan definisi. Menurut Organisation for Economic Cooperation and Development (OECD) (2009:97) tata kelola perusahaan adalah tentang mempromosikan keadilan perusahaan, transparansi dan akuntabilitas. J.Wolfensohn, President of World Bank (2005:12) mengungkapkan bahwa tata kelola perusahaan adalah bidang ekonomi yang menyelidiki bagaimana korporasi dapat dibuat lebih efisien dengan menggunakan struktur kelembagaan seperti kontrak, rancangan organisasi dan undang-undang.Menurut Shieifer and Vishny, The Journal of Finance (2007:5) tata kelola perusahaan dapat didefinisikan secara sempit sebagai hubungan perusahaan dengan pemegang sahamnya, secara lebih luas, karena hubungannya dengan masyarakat.

Definisi yang dikutip dari OECD memberikan penjelasan lebih lanjut bahwa struktur corporate governance memberikan spesifikasi tentang distribusi hak dan tanggung jawab antara berbagai peserta dalam perusahaan, seperti direksi, manajer, pemegang saham dan anggota stakeholder lainnya, dan menjelaskan aturan dan prosedur tentang pengambilan keputusan dalam perusahaan. Dengan ini, maka corporate governance memberikan stuktur melalui tujuan perusahaan dapat dicapai, dan dengan cara apa pencapaian tujuan tersebut dan dengan apa kinerja perusahaan dapat dimonitor.

Corporate governance adalah sistem manajemen yang berprinsip pada kejelasan tanggung jawab dan tugas, keadilan, transparansi, tanggung jawab, dan akuntabilitas. Semua entitas yang perlu pengelolaan dan dimana stakeholdernya menyangkut masyarakat luas, memerlukan good corporate governance. Oleh karena itu, sudah sejak lama perguruan tinggi di negaranegara maju sadar akan hal itu dan melaksanakan corporate governance di universitas masingmasing. Misalnya Canadian Association of University Teachers (CAUT) pada tahun 1993 menerbitkan tata kelola dan akuntabilitas: laporan kelompok studi independen tentang tata kelola universitas yang merupakan rekomendasi acuan untuk universitas-universitas di Kanada. Di Inggris, Committee of University Chairman (CUC) mengeluarkan model pernyataan mengenai corporate governance yang perlu dimasukkan pada setiap laporan tahunan universitas dan Guide for Members of Governing Bodies of Universities and Colleges in England, Wales and Northern Ireland.

Selanjutnya Corson (2006:118) mengatakan bahwa dalam perguruan tinggi, kita menyaksikan suatu proses atau seni dimana para cendekiawan, mahasiswa, pengajar, administrator, dan pimpinan bergabung bersama di kolege atau universitas serta melaksanakan peraturan dan ketentuan yang bertujuan meminimalkan konflik, meningkatkan kerja sama, dan menjamin kebebasan individu tertentu. Sedangkan Milett (2006:93) memberikan definisi governance sebagai tindakan untuk memutuskan apa yang harus dilakukan dan bagaimana melakukannya dalam sebuah organisasi. Dalam tata kelola universitas melibatkan keputusan tentang tujuan dasar atau misi perusahaan, tentang kebijakan (nilai) yang harus diamati dan dicapai dalam mengejar misi dasar, tentang program yang akan dilakukan dan tentang sumber daya yang 
akan diperoleh dan dimanfaatkan. Tata kelola juga melibatkan keputusan tentang tujuan pendaftaran, pengaturan organisasi, standar personalia, persyaratan fasilitas, kebutuhan informasi, alokasi anggaran, dan proses evaluasi. Di Indonesia kesadaran hal itu secara implisit tersirat dari pembuatan ketentuan-ketentuan yang tercantum dalam undang-undang mengenai yayasan ataupun peraturan pemerintah tentang Badan Hukum Milik Negara dan Badan Hukum Pendidikan untuk perguruan tinggi negeri.

\section{METODE}

Penelitian implementasi tata kelola layanan publik untuk mewujudkan good governance pada perguruan tinggi di Unesa merupakan penelitian studi kasus dengan pendekatan kualitatif yang disajikan secara deskriptif, atau dengan kata lain penelitian ini merupakan penelitian deskriptif kualitatif.Adapun subjek yang dimaksud dalam penelitian ini adalah senat, rektor dan pembantu rektor, kepala biro, dekan dan pembantu dekan, pejabat struktural, dosen, pimpinan unit, karyawan.Senat, rektor dan pembantu rektor, kepala biro, dekan dan pembantu dekan, pejabat struktural, dosen, pimpinan unit, karyawanmerupakan sumber data atau informan kunci (key informan) karena mereka merupakan orang yang mempunyai tanggung jawab memberikan pelayanan publikuntuk mewujudkan good governanace. Pengumpulan data dilakukan dengan teknik wawancara, observasi, dan studi dokumentasi.

\section{HASIL}

Penerapan good governance pada perguruan tinggi dengan menggunakan beberapa prinsip, yaitu: transparansi (transparancy), kemandirian (independence), akuntabilitas (accountability), pertanggungjawaban (res ponsibility), kesetaraan dan kewajaran (fairness).

\section{Prinsip Transparansi (Transparency)}

Prinsip transparansi dalam pengambilan datanya dilakukan dengan metode wawancara dan dokumentasi. Informan dalam prinsip transparansi dintaranya rektor; wakil rektor bidang umum dan keuangan; wakil dekan bidang umum dan keuangan FE, FT dan FIK; kepala
BAUK; kepala LPPM; kepala Unit Layanan Pengadaan; kepala puskom; dan 10 ketua program studi di lingkungan Unesa.

Wawancara dilakukan untuk mengetahui proses transparansi yang dilakukan oleh unit kerja yang ada di lingkungan Unesa, selain wawancara juga dilakukan analisis dokumen yang terkait dengan transparansi diantaranya dokumen Surat Pertanggung Jawaban keuangan Unesa tahun anggaran 2013-2016, dokumen pengadaan barang dan jasa Unesa tahun anggaran 2013-2016, Beban Kerja Dosen tahun 2013-2016, dokumen remunerasi, laporan Kinerja Pegawai Unesa tahun 2013-2016. Langkah-langkah dalam prinsip transparansi yang dilakukan oleh top management yaitu melakukan mengesahan terhadap Standar Operasional Prosedur (SOP) terhadap beberapa proses diantaranya: pengesahan barang dan jasa, penghitungan dan tindak lanjut terhadap dokumen Beban Kinerja Dosen, dan penghitungan dan tindak lanjut terhadap dokumen Laporan Kinerja Pegawai.Jadwal program kerja dalam kegiatan transparansi harus dimanfaatkan secara baik oleh semua kepentingan karena hal ini apabila tidak dimanfaatkan dengan baik akan berdampak pada unit kerja yang lainnya yang masih ada hubungannya dengan pekerjaan tersebut. Penyusunan program kerja prinsip transparansi merupakan suatu prinsip yang perlu diperhatikan dalam penyusunan program kerja prinsip-prinsip lainnya dalam mewujudkan good governance.

Prinsip transparansi melibatkan semua pihak mulai top management yaitu rektor; wakil rektor bidang umum dan keuangan; dan kepala BAUK. Middle management diwakili oleh dekan, wakil dekan bidang umum dan keuangan. Lower management diwakili oleh ketua jurusan, ketua program studi dan ketua laboratorium. Hasil dari prinsip transparansi adalah tanggung jawab atas kewajiban keterbukaan informasi serta menyediakan informasi bagi stakeholders sehingga posisi dan pengelolaan perguruan tinggi dapat mencerminkan kondisi riil dan harapan terhadap perguruan tinggi di masa yang akan datang.

Prinsip transparansi dalam pelaksanaannya Unesa bertanggung jawab atas kewajiban keterbukaan informasi serta menyediakan informasi bagi stakeholders sehingga posisi dan pengelolaan Unesa dapat mencerminkan kondisi riil dan harapan terhadap Unesa di masa 
yang akan datang.Senat, rektor dan pembantu rektor, kepala biro, dekan dan pembantu dekan, pejabat struktural, dosen, pimpinan unit, karyawan Unesa telah memiliki pemahaman transparansi yang komprehensif mengenai tata kelola layanan publik untuk mewujudkan good governance. Beberapa bentuk transparansi proses pengambilan keputusan yang telah diterapkan di Unesa antara lain melalui pengembangan infrastruktur informasi berupa internet yaitu website Unesa www.unesa.ac.id. Website menyediakan informasi berupa pengumuman, berita, artikel dan informasi lainnya yang dapat diakses oleh stakeholders.

Transparansi kepada mitra kerja, Unesa telah menerapkan aplikasi e-procurement dan e-tender (e-auction) dan implementasi modul pemasok manajemen dalam proses pengadaan barang dan jasa yang berpusat di ULP (Unit Layanan Pengadaan). Dengan e-procurement, kontak fisik antara pemasok/mitra dengan panitia diminimalkan dan semua kegiatan tender dilakukan dengan sistem komputer sehingga menunjang transparansi. Seluruh pemasok memperoleh informasi yang sama.

Transparansi penilaian kinerja dosen dan karyawandengan menggunakan kompetensi assessment tools, melaluipenilaian dilakukan secara langsung, yang melibatkan pegawai yang bersangkutan, atasan langsungserta dokumen nilai kinerja individu. Untuk menjaga obyektivitas dalam menjalankan tugas dan tanggungjawabnya, Unesa telah menyediakan informasi yang relevan dengan cara yang mudah diakses dan dipahami oleh pemangku kepentingan yaitu dengan mengembangkan aplikasi SIMUNA (Sistem Informasi Remunerasi Unesa) dan aplikasi SIMPEG (Sistem Informasi Pegawai).

\section{Prinsip Kemandirian (Independency)}

Berkaitan dengan aspek kemandirian, rektor dan senat memiliki pendapat yang independen dalam setiap keputusan yang diambil. Sedangkan penerapan kemandirian di bidang SDM dapat dilakukan dalam penunjukan pejabat di tingkat tertentu. Kandidat yang terpilih (short listed candidates) ditentukan melalui job tender, sidang jabatan dan assessment tools melalui assessment center, dengan memperhatikan hasil nilai kinerja individu, assessment online dan assessment center.
Prinsip kemandirian dalam pengambilan datanya dilakukan dengan metode wawancara dan dokumentasi. Informan dalam prinsip kemandirian diantaranya rektor, wakil rektor bidang akademik, wakil rektor bidang umum dan keuangan, wakil rektor bidang kemahasiswaan dan alumni, wakil rektor bidang kerjasama dan senat universitas.

Unesa senantiasa mengutamakan kesesuaian di dalam pengelolaan lembaganya menurut peraturan perundang-undangan yang berlaku dan prinsip-prinsip institusi yang sehat dan berkualitas. Setiap bagian/unit memiliki tugas dan fungsi masing-masing yang jelas, dengan alokasi tanggung jawab masing-masing secara jelas tercantum dalam kebijakan peraturan perguruan tinggi (Peraturan Rektor).

Senat, rektor dan pembantu rektor, kepala biro, dekan dan pembantu dekan, pejabat struktural, dosen, pimpinan unit, karyawan Unesa telah memiliki pemahaman kemandirian yang komprehensif mengenai tata kelola layanan publik untuk mewujudkan good governance. Untuk melancarkan pelaksanaan asas good governance, Unesa telah dikelola secara independen sehingga masing-masing unit kerja tidak saling mendominasi dan tidak dapat diintervensi oleh pihak lain. Tidak terdapat kendala kemandirian yang berarti dalam implementasi tata kelola layanan publik untuk mewujudkan good governance yang dialami oleh senat, rektor dan pembantu rektor, kepala biro, dekan dan pembantu dekan, pejabat struktural, dosen, pimpinan unit, karyawan Unesa.

\section{Prinsip Akuntabilitas (Accountability)}

Senat, rektor dan pembantu rektor, kepala biro, dekan dan pembantu dekan, pejabat struktural, dosen, pimpinan unit, karyawan Unesa telah memiliki pemahaman akuntabilitas yang komprehensif mengenai tata kelola layanan publik untuk mewujudkan good governance. Berkaitan dengan aspek kemandirian, rektor, dan senat memiliki pendapat yang independen dalam setiap keputusan yang diambil. Selain itu, dimungkinkan pula untuk memperoleh saran dari konsultan independen dan konsultan legal untuk menunjang kelancaran rektor.

Unesa telah mempertanggungjawabkan kinerjanya secara transparan dan wajar. Untuk itu Unesa sudah dikelola secara benar, terukur 
dan sesuai dengan kepentingan lembaga dengan tetap memperhitungkan kepentingan pemangku kepentingan lain. Akuntabilitas merupakan prasyarat yang diperlukan untuk mencapai kinerja yang berkesinambungan. Tidak terdapat kendala akuntabilitas yang berarti dalam implementasi tata kelola layanan publik untuk mewujudkan good governance yang dialami oleh senat, rektor dan pembantu rektor, kepala biro, dekan dan pembantu dekan, pejabat struktural, dosen, pimpinan unit, karyawan Unesa.

\section{Prinsip Pertanggungjawaban(Responsibility)}

Untuk menjunjung tinggi akuntabilitas, diperlukan kejelasan fungsi, pelaksanaan dan pertanggungjawaban semua unit dalam organisasi, sehingga pengelolaan lembaga terlaksana secara efektif. Senat, rektor dan pembantu rektor, kepala biro, dekan dan pembantu dekan, pejabat struktural, dosen, pimpinan unit, karyawan Unesa telah memiliki pemahaman pertanggungjawaban yang komprehensif mengenai tata kelola layanan publik untuk mewujudkan good governance.

Sejak ditetapkan menjadi PK-BLU Unesa pada tanggal 27 Februari 2009 oleh Menteri Keuangan dengan Surat Keputusan No. 50/KMK.05/2009 maka Unesa juga harus menerapkan pola pengelolaan keuangan Badan Layanan Umum dengan prinsip fleksibilitas dalam pengelolaan keuangan, peningkatan pelayanan kepada masyarakat dalam rangka memajukan kesejahteraan umum dan mencerdaskan kehidupan bangsa, dan penerapan praktek bisnis yang sehat. Selain itu setelah Unesa menjadi PK-BLU terjadi pula perubahan untuk hal-hal berikut ini: (1) semua penerimaan dana dari PNBP dapat langsung dioperasionalkan tanpa harus disetorkan ke KPPN, (2) penggunaan dana PNBP dilaporkan setiap penyampaian laporan keuangan per triwulan, (3) dan dalam upaya peningkatan layanan di bidang keuangan maka mulai bulan Januari 2010 sistem pembayaran gaji dan tunjangan langsung dibayarkan melalui proses perbankkan yaitu langsung ke rekening masing masing pegawai.

\section{Prinsip Kesetaraan dan Kewajaran (Fairness)}

Untuk memenuhi aspek kesetaraan dan kewajaran dalam penyampaian informasi, Unesa dapat menerapkan equal treatment kepada seluruh civitas akademika. Senat, rektor dan pembantu rektor, kepala biro, dekan dan pembantu dekan, pejabat struktural, dosen, pimpinan unit, karyawan Unesa telah memiliki pemahaman kesetaraan dan kewajaran yang komprehensif mengenai tata kelola layanan publik untuk mewujudkan good governance.

Hubungan dengan dosen dan karyawan juga terus dijaga, yaitu dengan menghindari praktek diskriminasi, antara lain menghormati hak asasi dosen dan karyawan, memberi kesempatan yang sama tanpa membedakan umur, suku, ras, agama dan jenis kelamin, memperlakukan dosen dan karyawan sebagai sumber daya yang berharga melalui sarana sistem knowledge based management. Dalam menjamin kewajaran dalam pelaksanaan dan sistem remunerasi, perlu ditetapkan mekanisme yang berkaitan dengan penetapan reward dan punishment bagi semua dosen dan karyawan. Selain itu, Unesa dapat secara berkala mengadakan survei mengenai tingkat remunerasi pada perguruan tinggi lain yang telah menerapkan sistem remunerasi sebagai bahan evaluasi remunerasi bagi dosen dan karyawan.

\section{PEMBAHASAN}

Penerapan good governance pada perguruan tinggi dengan menggunakan beberapa prinsip, yaitu: transparansi (transparancy), kemandirian (independence), akuntabilitas (accountability), pertanggungjawaban (responsibility), kesetaraan dan kewajaran (fairness). Untuk memberikan gambaran penerapan tata kelola di perguruan tinggi, dapat dikemukakan hal-hal sebagai berikut.

Transparansi (Transparency), berdasarkan temuan penelitian yang telah dilakukan menunjukkan Unesa telah menyediakan informasi secara tepat waktu, memadai, jelas, akurat dan dapat diperbandingkan serta mudah diakses oleh pemangku kepentingan sesuai dengan haknya. Prinsip keterbukaan yang dianut oleh Unesa tidak mengurangi kewajiban untuk memenuhi ketentuan kerahasiaan universitas sesuai dengan peraturan perundang-undangan, rahasia jabatan, dan hak-hak pribadi. Kebijakan Unesa telah tertulis dan secara proporsional dikomunikasikan kepada pemangku kepentingan.Hal ini sesuai dengan Organisation for Economic Cooperation and Development (OECD) (2009:89) yaitu perguruan tinggi bertanggung jawab atas kewajiban 
keterbukaan informasi serta menyediakan informasi bagi stakeholders sehingga posisi dan pengelolaan perguruan tinggi dapat mencerminkan kondisi riil dan harapan terhadap perguruan tinggi di masa yang akan datang.

Pelaksanaan transparansi di Unesa adalah pada proses pengambilan keputusan antara lain melalui pengembangan infrastruktur informasi berupa intranet, knowledge management, yang merupakan sarana karyawan dalam menyampaikan berbagai informasi berupa tulisan, ide-ide, atau gagasan.Transparansi kepada mitra kerja dapat menerapkan aplikasi e-procurement dan e-tender (e-auction) dan implementasi modul pemasok manajemen dalam proses pengadaan barang dan jasa.Transparansi penilaian kinerja pegawai dengan menggunakan kompetensi assessment tools, melalui assessment online penilaian dilakukan secara langsung yang melibatkan pegawai yang bersangkutan, atasan langsung, rekan sekerja dan bawahan serta dokumen nilai kinerja individu.

Beberapa temuan mengenai kemandirian yaitu sebagai berikut: masing-masing unit kerja di Unesa telah menghindari terjadinya dominasi oleh pihak manapun, tidak terpengaruh oleh kepentingan tertentu, bebas dari benturan kepentingan dan dari segala pengaruh atau tekanan, sehingga pengambilan keputusan dapat dilakukan secara obyektif. Masing-masing unit kerja di Unesa telah melaksanakan fungsi dan tugasnya sesuai dengan anggaran dasar dan peraturan perundang-undangan, tidak saling mendominasi dan atau melempar tanggung jawab antara satu dengan yang lain sehingga terwujud sistem pengendalian internal yang efektif.

Hal ini sesuai dengan Organisation for Economic Cooperation and Development (OECD) (2009:124) yaitu perguruan tinggi berkaitan dengan aspek kemandirian, rektor dan senat memiliki pendapat yang independen dalam setiap keputusan yang diambil. Sedangkan penerapan kemandirian di bidang SDM dapat dilakukan dalam penunjukan pejabat di tingkat tertentu. Kandidat yang terpilih (short listed candidates) ditentukan melalui job tender, sidang jabatan dan assessment tools melalui assessment center, dengan memperhatikan hasil nilai kinerja individu, assessment online dan assessment center.
Implementasi akuntabilitas diantaranya sebagai berikut: Unesa telah menetapkan rincian tugas dan tanggung jawab masing-masing unit organisasi dan semua karyawan secara jelas dan selaras dengan visi, misi, indikator kinerja utama. Unesa meyakini bahwa semua organisasi universitas dan semua dosen dan karyawan mempunyai kompetensi sesuai dengan tugas, tanggung jawab, dan perannya dalam pelaksanaan good governance. Unesa telah memastikan adanya sistem pengendalian internal yang efektif dalam pengelolaan universitas baik dari segi akademik (Pusat Penjaminan Mutu/PPM) maupun keuangan (Satuan Pengawasan Internal/ SPI).Unesa memiliki ukuran kinerja untuk semua jajaran yang konsisten dengan nilai-nilai universitas, indikator kinerja utamauniversitas, serta memiliki sistem penghargaan dan sanksi (reward and punishment system). Dalam melaksanakan tugas dan tanggung jawabnya, dosen dan karyawan harus berpegang pada peraturan akademik yang telah disepakati.

Hal ini sesuai dengan Organisation for Economic Cooperation and Development (OECD) (2009:166) yaitu perguruan tinggi berkaitan dengan akuntabilitas Untuk menjunjung tinggi akuntabilitas, diperlukan kejelasan fungsi, pelaksanaan dan pertanggungjawaban semua unit dalam organisasi, sehingga pengelolaan lembaga terlaksana secara efektif. Pelaksanaan akuntabilitas di Unesa adalah aspek akuntabilitas dalam penyampaian laporan keuangan sidang senat merupakan sarana rektor untuk mempertanggungjawabkan laporan keuangan tahunan lembaga, sementara itu penyampaian laporan keuangan tahunan dan tengah tahunan kepada publik dilaksanakan melalui media massa (media cetak) yang memiliki jangkauan luas. Selanjutnya aspek akuntabilitas dalam SDM Berkaitan dengan upaya meningkatkan kinerja SDM, diterapkan sistem reward dan punishment kepada karyawan yang dikaitkan dengan kebijakan kompensasi yang berlaku di internal perguruan tinggi.

Aspek pertanggungjawaban dalam penyampaian laporan keuangan sidang senat merupakan sarana rektor untuk mempertanggungjawabkan laporan keuangan tahunan dan laporan tersebut telah disetujui olehsenat. Selain itu, laporanlaporan rektor kepada senat mengenai rencana anggaran tahunan periode berjalan serta pem- 
bahasan rutin antara rektor dan senat mengenai evaluasi performasi keuangan triwulanan dan tahunan. Ini merupakan bentuk-bentuk penerapan good governance. Sementara itu, penyampaian laporan keuangan tahunan dan tengah tahunan kepada publik dilaksanakan melalui media massa (media cetak) yang memiliki jangkauan luas. Tahun 2015 Unesa telah meraih status WTP (Wajar Tanpa Pengecualian) yang artinya penggunaan keuangan Unesa tidak berpotensi adanya korupsi. Ini merupakan apresiasi yang sangat luar biasa dalam hal pertanggungjawaban yang sebelumnya menyandang status WDP (Wajar Dengan Pengecualian). Tidak terdapat kendala pertanggungjawaban yang berarti dalam implementasi tata kelola layanan publik untuk mewujudkan good governance yang dialami oleh senat, rektor dan pembantu rektor, kepala biro, dekan dan pembantu dekan, pejabat struktural, dosen, pimpinan unit, karyawan Unesa.

Hal ini sesuai dengan Organisation for Economic Cooperation and Development (OECD) (2009:210) universitas harus mengutamakan kesesuaian di dalam pengelolaan perguruan tingginya menurut peraturan perundang-undangan yang berlaku dan prinsip-prinsip institusi yang sehat dan berkualitas. Pelaksanaan pertanggungjawaban di Unesa berkaitan dengan akuntabilitas pertanggungjawabandalam SDM berkaitan dengan upaya meningkatkan kinerja SDM, diterapkan sistem reward dan punishment kepada dosen dan karyawan yang dikaitkan dengan kebijakan kompensasi yang berlaku di internal Unesa. Unesa telah mematuhi peraturan perundangundangan serta melaksanakan tanggung jawab terhadap masyarakat dan lingkungan sehingga dapat terpelihara kesinambungan usaha dalam jangka panjang dan mendapat pengakuan sebagai perguruan tinggi yang berkualitas. Unesa telah berpegang pada prinsip kehati-hatian dan memastikan kepatuhan terhadap peraturan perundang-undangan, anggaran dasar dan peraturan universitas. Unesa telah melaksanakan tanggung jawab sosial dengan antara lain peduli terhadap masyarakat dan kelestarian lingkungan terutama di sekitar kampus dengan membuat perencanaan dan pelaksanaaan kampus yang ramah lingkungan atau eco campus, dan menjadi juara 1 piala Wali Kota Surabaya sebagai eco campus 2015.
Penjaminan kewajaran harga dalam proses pengadaan barang dan jasa dilakukan Unesa dengan menyediakan layanan lelang elektronik untuk penjualan dan pengadaan barang antar perusahaan atau organisasi yang bernama e-auction sebagai pondasi awal terbentuknya e-procurement. Sesuai Kepres No10/2012 mengenai Pengadaan Barang dan Jasa, prinsip-prinsip dalam procurement adalah efisien, efektif, terbuka dan bersaing, transparan, adil serta akuntabel. Melalui $e$ auction menciptakan transparansi, akuntabilitas dan efisiensi pelaksanaan lelang.Dalam melaksanakan kegiatannya, Unesa senantiasa memperhatikan kepentingan pemangku kepentingan berdasarkan asas kesetaraan dan kewajaran.

Tidak terdapat kendala kesetaraan dan kewajaran yang berarti dalam implementasi tata kelola layanan publik untuk mewujudkan good governance yang dialami oleh senat, rektor dan pembantu rektor, kepala biro, dekan dan pembantu dekan, pejabat struktural, dosen, pimpinan unit, karyawan Unesa.

Hal ini sesuai dengan Organisation for Economic Cooperation and Development (OECD) (2009: 230) mengenai kesetaraan dan kewajaran untuk memenuhi aspek kesetaraan dan kewajaran dalam penyampaian informasi, perguruan tinggi dapat menerapkan equal treatment kepada seluruh civitas akademika. Dalam menjamin kewajaran harga dalam proses pengadaan barang dan jasa, perguruan tinggi menyediakan layanan lelang elektronik untuk penjualan dan pengadaan barang antar perusahaan atau organisasi yang bernama e-auction sebagai pondasi awal terbentuknya e-procurement.

Pelaksanaan kesetaraan dan kewajaran di Unesa memberikan kesempatan kepada pemangku kepentingan untuk memberikan masukan dan menyampaikan pendapat bagi kepentingan universitas serta membuka akses terhadap informasi sesuai dengan prinsip transparansi dalam lingkup kedudukan masingmasing. Unesa telah memberikan perlakuan yang setara dan wajar kepada pemangku kepentingan sesuai dengan manfaat dan kontribusi yang diberikan kepada universitas. Unesa memberikan kesempatan yang sama dalam penerimaan dosen dan karyawan, berkarir dan melaksanakan tugasnya secara profesional tanpa membedakan suku, agama, ras, jender, dan kondisi fisik. 


\section{KESIMPULAN DAN SARAN}

\section{Kesimpulan}

Transparansi (Transparency) yang dilakukan Unesadengan menyediakan informasi secara tepat waktu, memadai, jelas, akurat dan dapat diperbandingkan serta mudah diakses oleh pemangku kepentingan sesuai dengan haknya. Prinsip keterbukaan yang dianut oleh Unesa tidak mengurangi kewajiban untuk memenuhi ketentuan kerahasiaan universitas sesuai dengan peraturan perundang-undangan, rahasia jabatan, dan hak-hak pribadi.

Kemandirian (Independency) diwujudkan pada masing-masing unit kerja di Unesa dengan menghindari terjadinya dominasi oleh pihak manapun, tidak terpengaruh oleh kepentingan tertentu, bebas dari benturan kepentingan dan dari segala pengaruh atau tekanan, sehingga pengambilan keputusan dapat dilakukan secara obyektif. Masing-masing unit kerja di Unesa telah melaksanakan fungsi dan tugasnya sesuai dengan anggaran dasar dan peraturan perundangundangan, tidak saling mendominasi dan atau melempar tanggung jawab antara satu dengan yang lain sehingga terwujud sistem pengendalian internal yang efektif.

Akuntabilitas (Accountability) dilakukan Unesa dengan menetapkan rincian tugas dan tanggung jawab masing-masing unit organisasi dan semua karyawan secara jelas dan selaras dengan visi, misi, indikator kinerja utama universitas. Unesa meyakini bahwa semua organisasi universitas dan semua dosen dan karyawan mempunyai kompetensi sesuai dengan tugas, tanggung jawab, dan perannya dalam pelaksanaan good governance. Unesa telah memastikan adanya sistem pengendalian internal yang efektif dalam pengelolaan universitas baik dari segi akademik maupun keuangan. Unesa memiliki ukuran kinerja untuk semua jeajaran yang konsisten dengan nilai-nilai universitas, indikator kinerja utama universitas, serta memiliki sistem penghargaan dan sanksi (reward and punishmenrt system).

Pertanggungjawaban (Responsibility) diwujudkan dalam penyampaian laporan keuangan tahunan dan tengah tahunan kepada publik yang dilaksanakan melalui media massa (media cetak) yang memiliki jangkauan luas. Tahun 2015 Unesa telah meraih status WTP (Wajar Tanpa Pengecualian) yang artinya penggunaan keuangan Unesa tidak berpotensi adanya korupsi. Ini merupakan apresiasi yang sangat luat biasa dalam hal pertanggungjawaban, dan sebelumnya menyandang status WDP (Wajar Dengan Pengecualian).Unesa telah melaksanakan tanggung jawab sosial dengan antara lain peduli terhadap masyarakat dan kelestarian lingkungan terutama di sekitar kampusdengan membuat perencanaan dan pelaksanaaan kampus yang ramah lingkungan atau eco campus, dan menjadi juara 1 piala Wali Kota Surabaya sebagai eco campus 2015.

KesetaraandanKewajaran(Fairness)nampak pada hubungan dengan dosen dan karyawan yang terus dijaga, yaitu dengan menghindari praktik diskriminasi, antara lain menghormati hak asasi dosen dan karyawan, memberi kesempatan yang sama tanpa membedakan umur, suku, ras, agama dan jenis kelamin, memperlakukan karyawan sebagai sumber daya yang berharga melalui sarana sistem knowledge based management. Dalam menjamin kewajaran dalam pelaksanaan dan sistem remunerasi, perlu ditetapkan mekanisme yang berkaitan dengan penetapan reward dan punishment bagi semua dosen dan karyawan. Selain itu, Unesa dapat secara berkala mengadakan survei mengenai tingkat remunerasi pada perguruan tinggi lain sebagai bahan evaluasi remunerasi bagi dosen dan karyawan. Dalam menjamin kewajaran harga dalam proses pengadaan barang dan jasa, Unesa menyediakan layanan lelang elektronik untuk penjualan dan pengadaan barang antar perusahaan atau organisasi yang bernama e-auction sebagai pondasi awal terbentuknya e-procurement. Melalui e-auction menciptakan transparansi, akuntabilitas dan efisiensi pelaksanaan lelang. Dalam melaksanakan kegiatannya, Unesa senantiasa memperhatikan kepentingan pemangku kepentingan berdasarkan asas kesetaraan dan kewajaran. Unesatelah memberikan kesempatan kepada pemangku kepentingan untuk memberikan masukan dan menyampaikan pendapat bagi kepentingan universitas serta membuka akses terhadap informasi sesuai dengan prinsip transparansi dalam lingkup kedudukan masing-masing. 


\section{Saran}

Berdasarkan kesimpulan di atas dapat diuraikan saran kepada pihak-pihak yang berkepentingan sebagai berikut. Pertama, kepada rektor dan wakil rektor dalam menyusun kebijakan tertulis dan secara proporsional dikomunikasikan kepada semua pemangku kepentingan serta sebaiknya memberikan perlakuan yang setara dan wajar kepada pemangku kepentingan sesuai dengan manfaat dan kontribusi yang diberikan kepada universitas. Kedua, wakil rektor bidang umum dan keuanganmenerapkan sistem reward dan punishment kepada dosen dan karyawan yang dikaitkan dengan kebijakan kompensasi yang berlaku di internal Unesa. Ketiga, pimpinan unit kerja di Unesa sebaiknya selalu menghindari terjadinya dominasi, pengaruh, benturan kepentingan, serta pengaruh atau tekanandari pihak manapun. Keempat, dosen dan karyawan dalam melaksanakan tugas dan tanggung jawabnya harusberpegang pada peraturan akademik yang telah disepakati.

\section{DAFTAR RUJUKAN}

Aristo, A.D., 2005. Good University Governance. http://aristodiga.blogspot.com/ 2005/08/gooduniversity-governance.html.

Brojonegoro, 2005. Trilogy of Governance: Corporate Governance. http://www. republika.co.id/suplemen/cetak_detail. asp? $\mathrm{mid}=3 \& \mathrm{id}=155434 \& \mathrm{~kat} \_\mathrm{id}=105 \& \mathrm{~kat}$ id $1=149 \&$ kat_id $2=313$.

Corson, 2006. Pedoman Umum Good Corporate Governance. http://www.cic-fcgi.org/ news/files/ Pedoman_GCG_060906.pdf Kumorotomo, W., 2005. Akuntabilitas Birokrasi Publik Sketsa pada Masa Transisi. Pustaka Pelajar. Yogyakarta.

Millet. 2006. Accountability in Malaysian Higher Education. Universiti Sains Malaysia. Penang.

OECD. 2005. The New Standard and Accountability: Will Rewards and Sanctions Motivate America's Schools to Peak Performance. http://www.awsp. org. August 29, 2006. 